\title{
ІНФОРМАТИВНІСТЬ ТА ЕФЕКТИВНІСТЬ ПРОМЕНЕВИХ МЕТОДІВ У ДІАГНОСТИЦІ спОНДилІтІв
}

\author{
๑Н. В. Дереш' , О. П. Шармазанова² \\ 'Діагностичний центр «Омега-Київ», \\ ${ }^{2}$ Харківська медична академія післядипломної освіти
}

РЕЗЮМЕ. Золотим стандартом діагностики спондилітів $€$ культуральна чи патоморфологічна верифікація. Однак проведення інтервенційних хірургічних втручань з діагностичною метою при спондилітах має ряд обмежень. Результати біопсії потребують обережної інтерпретації, без візуалізаційної навігації можливі негативні результати, мають місце важливі методологічні проблеми та низька якість отриманого матеріалу. За неможливості гістологічної чи бактеріологічної верифікації променева діагностика стає єдиним критерієм підтвердження діагнозу.

Мета - визначити інформативність та ефективність рентгенографії, комп'ютерної томографії (КT), магнітнорезонансної томографії (МРТ), цифрового томосинтезу (ЦТ) та їх поєднань у діагностиці спондилітів.

Матеріал і методи. Проведено ретроспективне дослідження 140 дорослих пацієнтів, з них 54 з туберкульозним спондилітом, 41 з неспецифічним спондилітом та 45 осіб, які склали контрольну групу.

Результати. Визначені чутливість, специфічність, точність, прогностичність та ефективність кожного з променевих методів, а також комбінацій МРТ і КТ, МРТ і цифрового томосинтезу.

Висновки. МРТ виявився найкращим методом діагностики спондилітів. Це єдиний з методів, який дозволяє виявляти набряк кісткового мозку та має значні переваги у виявленні поширення процесу на спинний мозок, оболонки та інші м'які тканини. Дані КТ найкраще характеризують диференційні особливості кістково-деструктивного процесу і паравертебральних абсцесів. Поєднане застосування КТ+МРТ підвищує специфічність і точність діагностики. ЦТ підвищує діагностичні можливості рентгенологічного методу. 3 точки зору ефективності використання ресурсів та меншого променевого навантаження перспективним $є$ поєднання цифрового томосинтезу та МРТ.

КЛючОВІ СлОВА: спондиліт; рентгенографія; комп'ютерна томографія; магнітно-резонансна томографія; цифровий томосинтез; специфічність; чутливість; ефективність.

Вступ. Діагностика спондиліту базується на зіставленні клініко-лабораторних, бактеріологічних даних та результатів використання методів променевої діагностики [1]. Золотим стандартом діагностики $\epsilon$ культуральна чи патоморфологічна верифікація, а саме культуральне виділення та ідентифікація збудника, полімеразна ланцюгова реакція та гістопатологічний патерн $[2,3]$.

Результати біопсії потребують обережної інтерпретації, оскільки мають місце важливі методологічні проблеми та низька якість отриманого матеріалу. Біопсія без візуалізаційної навігації часто дає негативні результати. Результати росту мікроорганізмів складають 10-50 \% випадків [4]. Інтервенція при туберкульозному спондиліті без превентивної специфічної терапії може призвести до генералізації процесу. Тому проведення інтервенційних хірургічних втручань із діагностичною метою при спондилітах має ряд обмежень.

Променеві методи діагностики - єдині неінвазивні в прижиттєвому виявленні патологічних змін хребта. Результати променевих методів необхідні для встановлення діагнозу, для візуалізаційної навігації при черезшкірних біопсіях, диференційної діагностики, виявлення ускладнень, а також для контролю в динаміці та оцінки ефективності лікування хвороби $[1,6]$.
За неможливості гістологічної чи бактеріологічної верифікації позитивна клініко-радіологічна динаміка в результаті проведеної емпіричної терапії стає єдиним критерієм підтвердження діагнозу [5].

Мета - визначити інформативність та ефективність рентгенографії, комп'ютерної томографії (КT), магнітно-резонансної томографії (МРT), цифрового томосинтезу (ЦТ) та їх комбінацій у діагностиці спондилітів.

Матеріал і методи дослідження. Проведене ретроспективне дослідження 140 пацієнтів, з них 54 з туберкульозним спондилітом (ТC), 41 - з неспецифічним спондилітом (НC) та 45 - група порівняння (II група). Серед обстежених було 85 чоловіків та 55 жінок, середній вік $(50,6 \pm 1,33),(55,5 \pm 1,53)$, $(49,4 \pm 1,46)$ років відповідно. Розподіл пацієнтів за віком та статтю наведено в таблицях 1 i 2 .

Проаналізовані історії хвороби та дані променевих методів дослідження, що застосовувалися для діагностики спондилітів: рентгенографії, комп'ютерної томографії, магнітно-резонансної томографії, цифрового томосинтезу. У дослідження не включали дітей, пацієнтів з анкілозуючим спондилітом (хвороба Бехтєрєва), пацієнтів з серонегативними спондилоартропатіями, пацієнтів з пухлинними та метаболічними ураженнями хребта. Методи верифікації діагнозів представлені в таблиці 3. 
Огляди літератури, оригінальні дослідження, погляд на проблему, випадок з практики, короткі повідомлення Таблиця 1. Розподіл пацієнтів за віком

\begin{tabular}{|c|c|c|c|c|c|c|}
\hline \multirow{3}{*}{ Вік пацієнтів (роки) } & \multicolumn{4}{|c|}{$\begin{array}{c}\text { I група (спондиліти) } \\
\text { (n=95) }\end{array}$} & \multirow{2}{*}{\multicolumn{2}{|c|}{$\begin{array}{l}\text { II група (порівняльна) } \\
\text { (n=45) }\end{array}$}} \\
\hline & \multicolumn{2}{|c|}{$\mathrm{TC}(n=54)$} & \multicolumn{2}{|c|}{$\mathrm{HC}(\mathrm{n}=41)$} & & \\
\hline & $n$ & $\%$ & $n$ & $\%$ & $\mathrm{n}$ & $\%$ \\
\hline 25-44 - молодий вік & 20 & 37 & 7 & 17 & 18 & 40 \\
\hline 44-60 - середній вік & 13 & 24 & 19 & 46 & 18 & 40 \\
\hline 60-75 - похилий вік & 21 & 39 & 15 & 37 & 9 & 20 \\
\hline
\end{tabular}

Таблиця 2. Розподіл пацієнтів за статтю

\begin{tabular}{|c|c|c|c|c|c|c|c|c|c|c|c|}
\hline \multicolumn{8}{|c|}{ I група, n=95 } & \multirow{2}{*}{\multicolumn{4}{|c|}{ II група, n=45 }} \\
\hline \multicolumn{4}{|c|}{ підгрупа ТC (n=54) } & \multicolumn{4}{|c|}{ підгрупа HC (n=41) } & & & & \\
\hline \multicolumn{2}{|c|}{ жінки } & \multicolumn{2}{|c|}{ чоловіки } & \multicolumn{2}{|c|}{ жінки } & \multicolumn{2}{|c|}{ чоловіки } & \multicolumn{2}{|c|}{ жінки } & \multicolumn{2}{|c|}{ чоловіки } \\
\hline $\mathrm{n}=18$ & $33,3 \%$ & $\mathrm{n}=36$ & $66,7 \%$ & $\mathrm{n}=15$ & $36,6 \%$ & $n=26$ & $63,4 \%$ & $\mathrm{n}=22$ & $48,9 \%$ & $\mathrm{n}=23$ & $51,1 \%$ \\
\hline
\end{tabular}

Таблиця 3. Розподіл на основі методів верифікації діагнозу

\begin{tabular}{|l|c|c|c|c|}
\hline \multicolumn{1}{|c|}{ Методи верифікації } & \multicolumn{2}{|c|}{$\begin{array}{c}\text { туберкульозний спондиліт } \\
(\mathrm{n}=54)\end{array}$} & \multicolumn{2}{c|}{$\begin{array}{c}\text { Неспецифічний спондиліт } \\
(\mathrm{n}=41)\end{array}$} \\
\hline Гістологічна верифікація & 13 & $24 \%$ & 9 & $22 \%$ \\
\hline Бактеріологічна верифікація & 20 & $37 \%$ & 10 & $24 \%$ \\
\hline $\begin{array}{l}\text { Підтвердження на основі позитивної } \\
\text { клінічної та радіологічної картини }\end{array}$ & 53 & $98 \%$ & 40 & $97 \%$ \\
\hline
\end{tabular}

Променеві методи: аналогова рентгенографія виконувалася на апараті РуМ-20, цифрова рентгенографія - на рентгенодіагностичному апараті з цифровим приймачем. КТ проводилася на 16- та 64-зрізовому спіральних томографах, товщиною зрізів по 1,0-2,5 мм з мультипланарними та волюметричними реконструкціями, з використанням жорсткого (кісткового) та м'якого (тканинного) фільтрів Кернела з виконанням реконструкцій та волюметричним рендерінгом / 3D моделюванням хребта на робочих станціях (Vitrea, Philips Extended Brilliance ${ }^{\mathrm{TM}}$ Workspase V4.5). Цифровий томосинтез (ЦТ) виконувався на вітчизняному цифровому рентгенодіагностичному комплексі з режимом цифрового томосинтезу після виконання цифрової спондилографії. На кожне обстеження
ЦТ отримано 256 зображень кроком через 1 мм, що проглядалося у вигляді відеопетлі з можливістю постпроцесингу (лінійні, кутові заміри, площі, гістограми, оцінка при різній ширині вікна, масштабування) на стандартних DICOM в'юверах. Променеве навантаження розраховувалося за стандартними показниками і складало до 0,5 мЗв для цифрової рентгенограми, 0,6-0,8 мЗв для ЦТ, 8-12 м3в для КТ. Аналіз доповнювали опціями постпроцесингу на робочих станціях.

МРТ дослідження виконували на 1,0 Т та 1,5 Т апаратах із використанням спінальної котушки, використовуючи імпульсні послідовності Т1W, T2W, STIR, опціонально DWI, DCE. Розподіл пацієнтів за методами обстеження представлений у таблиці 4.

Таблиця 4. Частота використаних методів обстеження, n (\%)

\begin{tabular}{|c|c|c|c|}
\hline \multirow{2}{*}{ Методи дослідження } & \multicolumn{2}{|c|}{ I група (n=95) } & \multirow{2}{*}{ II група ( $n=45)$} \\
\hline & $\mathrm{TC}(n=54)$ & $\mathrm{HC}(\mathrm{n}=41)$ & \\
\hline Рентгенограма & $35(65 \%)$ & $20(49 \%)$ & $45(100 \%)$ \\
\hline KT & $50(93 \%)$ & $36(88 \%)$ & $45(100 \%)$ \\
\hline MPT & $32(59 \%)$ & $25(49 \%)$ & 40 (89 \%) \\
\hline ЦТ & $14(26 \%)$ & $12(61 \%)$ & $15(33 \%)$ \\
\hline $\mathrm{KT}+\mathrm{MPT}$ & $27(50 \%)$ & $20(49 \%)$ & $40(89 \%)$ \\
\hline ЦТ+МРТ & $9(17 \%)$ & $11(27 \%)$ & $15(33 \%)$ \\
\hline
\end{tabular}


Огляди літератури, оригінальні дослідження, погляд на проблему, випадок з практики, короткі повідомлення

Дані опрацьовували з використанням комплексу статистичних програм «Біостатистика», що включав у себе методи варіаційної статистики, кореляційного аналізу з використанням параметричних та непараметричних критеріїв. Чутливість, специфічність, точність та прогностичні показники вираховували за відомими формулами.

Істинно позитивним заключенням (ІПЗ) вважали вірний позитивний результат наявності в пацієнта патологічного процесу, виявленого за допомогою всіх використаних методів. Хибно негативним заключенням (ХНЗ) вважали помилковий висновок про відсутність патологічного стану в пацієнта. Істинно негативним заключенням (IH3) вважали вірний негативний результат про відсутність патологічного процесу. Хибно позитивним заключенням (ХПЗ) вважали помилковий діагностичний висновок про наявність патологічного процесу, який не був підтверджений при подальшому дослідженні.

Результати й обговорення. ТС найчастіше траплявся в людей похилого та молодого віку, 39 \% та 37 \% відповідно, гендерний розподіл ж : ч=1 : 2.

У переважної більшості пацієнтів із ТС, а саме в 40 (74 \% випадків), відзначався торпідний початок захворювання із стертими клінічними проявами. Близько 2/3 осіб, що захворіли, зверталися за допомогою в терміні від 1 до 6 місяців. Основною скаргою у 32 (59 \%) пацієнтів із ТС був біль у хребті, у 23 (43\%) - неврологічний компресійний синдром.

Гістопатоморфологічний патерн ТС (13 (24\%): у губчастій тканині тіл хребців вогнища специфічного запального процесу з формуванням епітеліоїдних гранульом у центрі з казеозним некрозом. Навколо центрів горбиків - вал із епітеліоїдних клітин, лімфоцити, макрофаги, плазматичні клітини, багатоядерні гігантські клітини Пирогова Лангханса. Сформовані порожнини в тілах (кавер- ни). Щільні казеозно-некротичні та ексудативні маси, кальцинати, некротичні секвестри. Ідентифікація збудника - у 20 (37\%) M. tuberculosis.

За частотою ураження відзначено, що грудний відділ хребта постраждав у 29 (54 \%) пацієнтів, попереково-крижовий -у 18 (33\%). Коморбідність: асоціація з легеневим туберкульозом виявлена у 23 (43\%) пацієнтів.

Серед обстежених неспецифічний спондиліт найчастіше зустрічався в людей середнього та похилого віку (46 \% та 37 \% відповідно), гендерний розподіл - ж : ч=1 : 1,7.

У переважної більшості пацієнтів з НС, а саме у 32 (78\%), захворювання мало гострий початок із вираженими клінічними проявами. 90 \% осіб, що захворіли, зверталися за допомогою в строки до 1 міс. Біль у хребті високої інтенсивності був основною скаргою в 23 (42 \%) пацієнтів з НС, неврологічний компресійний синдром - у 21 (51\%). Гістологічна верифікація проведена у 9 (22 \%) випадках неспецифічних спондилітів.

Гістопатоморфологічний патерн НС: у губчастій речовині хребців ділянки гнійно-некротичного запального процесу з вираженою лейкоцитарною інфільтрацією. Товста піогенна капсула абсцесів з вираженою клітинною інфільтрацією, ексудативні маси, секвестри. Ідентифікація збудника у 10 (24\%) - Staphylococcus aureus, Streptococcus pyogenes, Pseudomonas aeruginosa, Staphylococcus epidermidis.

За частотою ураження розподіл виявився таким - ураження грудного відділу хребта виявлено в 11 (27\%) хворих, попереково-крижового - в 24 (59 \%). Коморбідність: асоціація з цукровим діабетом - у 23 (43\%), з оперативними втручаннями - у 13 (32\%) пацієнтів.

Можливості променевих методів у діагностиці спондилітів за їх променевими ознаками представлено в таблицях 5, 6.

Таблиця 5. Можливості променевих методів в діагностиці спондилітів

\begin{tabular}{|c|c|c|c|c|}
\hline $\begin{array}{c}\text { Запальні зміни елементів } \\
\text { хребтового сегмента }\end{array}$ & РГ & KT & MPT & ЦТ \\
\hline $\begin{array}{l}\text { Дисцит } \\
\text { Ознака }\end{array}$ & $\begin{array}{c}-/+ \\
\text { висота диска }\end{array}$ & $\begin{array}{c}-/+ \\
\text { висота диска }\end{array}$ & $\begin{array}{c}+++ \\
\text { висота диска + } \\
\text { структурні зміни }\end{array}$ & $\begin{array}{c}-/+ \\
\text { висота диска }\end{array}$ \\
\hline Внутрішньодисковий абсцес & - & -/+ контраст & ++ & - \\
\hline Кісткова деструкція & + & +++ & + & +++ \\
\hline Набряк кісткового мозку & - & - & +++ & - \\
\hline $\begin{array}{l}\text { Інфільтрація паравертебральних } \\
\text { м'яких тканин }\end{array}$ & - & $-/+$ & +++ & - \\
\hline Паравертебральний абсцес & + & ++ & +++ & + \\
\hline Кальцинати в абсцесі & + & ++ & - & + \\
\hline Газ & + & + & - & + \\
\hline Епідуральний абсцес & - & + & +++ & + \\
\hline Мозкові оболонки & - & -/+ контраст & +++ & - \\
\hline Спинний мозок & - & -/+ контраст & +++ & - \\
\hline
\end{tabular}


Огляди літератури, оригінальні дослідження, погляд на проблему, випадок з практики, короткі повідомлення Таблиця 6. Променеві ознаки спондилітів за частотою, n (\%)

\begin{tabular}{|c|c|c|}
\hline Ознака & TC $(n=54)$ & $\mathrm{HC}(n=41)$ \\
\hline $\begin{aligned} & \text { Локалізація } \\
& \checkmark \text { Шийний відділ } \\
& \checkmark \text { Шийно-грудний відділ } \\
& \checkmark \text { Грудний відділ } \\
& \checkmark \text { Грудо-поперековий відділ } \\
& \checkmark \text { Попереково-крижовий відділ }\end{aligned}$ & $\begin{array}{c}1(2 \%) \\
1(2 \%) \\
29(54 \%) \\
5(9 \%) \\
18(33 \%)\end{array}$ & $\begin{array}{c}3(7 \%) \\
- \\
11(27 \%) \\
3(7 \%) \\
24(59 \%)\end{array}$ \\
\hline Набряк кісткового мозку & $23 / 32(72 \%)$ & $24 / 24(100 \%)$ \\
\hline \multirow{2}{*}{$\begin{array}{l}\text { Деструкція тіл хребців } \\
\checkmark \text { Поверхнева (замикальні пластини) } \\
\checkmark \text { Осередкова }\end{array}$} & $47(87 \%)$ & $39(95 \%)$ \\
\hline & $\begin{array}{l}20 \\
27\end{array}$ & $\begin{array}{l}31 \\
8\end{array}$ \\
\hline \multirow{2}{*}{$\begin{array}{l}\text { Секвестри } \\
\checkmark \text { Кортикальні } \\
\checkmark \text { Губчасті }\end{array}$} & $27(50 \%)$ & $22(53 \%)$ \\
\hline & $\begin{array}{l}13 \\
22\end{array}$ & $\begin{array}{c}22 \\
2\end{array}$ \\
\hline Каверна & $22(40 \%)$ & - \\
\hline Газ у тілі хребця & - & $15(36,58 \%)$ \\
\hline Зниження висоти диска & $49(91 \%)$ & $36(87,8 \%)$ \\
\hline 3більшення висоти диска & $5(9 \%)$ & $4(9,75 \%)$ \\
\hline Моносегментарне ураження & $38(70 \%)$ & $31(75,61 \%)$ \\
\hline Полісегментарне ураження & $16(30 \%)$ & $10(24,39 \%)$ \\
\hline Скіп (перестрибування) & $7(13 \%)$ & $3(7,31 \%)$ \\
\hline Черездискове поширення & 49 (91\%) & $40(97,5 \%)$ \\
\hline Сублігаментарне поширення & $29(54 \%)$ & $19(46,3 \%)$ \\
\hline Паравертебральний абсцес & $36(67 \%)$ & $28(68,29 \%)$ \\
\hline Епідуральний абсцес & $31(57 \%)$ & $15(36,59 \%)$ \\
\hline Звапнення/кальцинати в абсцесі & $18(33 \%)$ & - \\
\hline Газ в абсцесі & - & $11(26,83 \%)$ \\
\hline Газ у тілі хребця & - & $3(7,31 \%)$ \\
\hline Деформації хребта & $31(57 \%)$ & $10(24,39 \%)$ \\
\hline Гібус & $12(22 \%)$ & $3(7,31 \%)$ \\
\hline Кістковий блок & $9(17 \%)$ & - \\
\hline Залишкова каверна & $5(9 \%)$ & - \\
\hline
\end{tabular}

Ефективність застосування променевих методів узагальнено в таблиці 7.

Із даних, наведених в таблиці 5, видно, що МРТ - єдиний з методів, який дозволяє виявляти набряк кісткового мозку та має значні переваги у виявленні поширення процесу на спинний мозок, оболонки мозку та інші м'які тканини. Дані КТ найкраще характеризують кістково-деструктив- ний процес та виявлення газу і кальцинатів у тканинах.

Із даних, наведених у таблиці 6, видно, що радіологічна семіотика ТС та НС має відмінності за локалізацією, характеристиками кістково-деструктивного процесу та паравертебральних абсцесів, що дозволяє провести променеву диференційну діагностику.

Таблиця 7. Інформативність та ефективність променевих методів у діагностиці спондилітів

\begin{tabular}{|l|c|c|c|c|c|c|c|c|c|}
\hline \multicolumn{1}{|c|}{ Методи } & ІПЗ & IH3 & ХН3 & ХП3 & ч\% & С\% & Т\% & П\% & Е\% \\
\hline РГ & 16 & 10 & 15 & 7 & 51,61 & 58,82 & 54,17 & 69,57 & 33,33 \\
\hline КТ & 66 & 22 & 10 & 5 & 86,84 & 81,48 & 85,48 & 92,96 & 64,08 \\
\hline МРТ & 57 & 16 & 0 & 5 & 100 & 76,19 & 93,59 & 91,94 & 73 \\
\hline ЦТ & 15 & 8 & 3 & 3 & 83,33 & 72,72 & 79,31 & 83,33 & 51,72 \\
\hline КТ+МРТ & 48 & 26 & 0 & 3 & 100 & 92,86 & 96,10 & 94,12 & 62,34 \\
\hline ЦТ МРТ & 20 & 10 & 0 & 2 & 100 & 83,33 & 93,75 & 90,91 & 62,5 \\
\hline
\end{tabular}

Примітка. * Ч - чутливість, С - специфічність, Т - точність, П-прогностичність, Е-ефективність. 
Огляди літератури, оригінальні дослідження, погляд на проблему, випадок з практики, короткі повідомлення

Використання ЦТ дозволяє вірогідно підвищити специфічність і точність рентгенографії на 13,9 \% та 25,17 \% відповідно. 3 даних, наведених у таблиці 7, визначено, що за показниками чутливості, точності, прогностичності та ефективності МРТ випереджає інші методи радіологічної візуалізації. Було розглянуто два варіанти комплексного застосування методів: КТ+МРТ та ЦТ+МРТ. Поєднане застосування методів підвищує специфічність і точність діагностики, порівняно з МРТ, зокрема, КТ+МРТ - на 21,9 \% та 2,7 \% відповідно. Поєднання ЦТ+МРТ підвищує специфічність діагностики на 9,4 \%, порівняно лише з МРТ. 3 точки зору ефективності використання ресурсів другий варіант, а саме ЦТ+МРТ, виявився кращим за поєднання КТ+МРТ. ЦТ підвищує діагностичні можливості рентгенологічного методу.

\section{ЛІТЕРАТУРА}

1. Загальні принципи діагностики туберкульозного спондиліту / Г. Г. Голка, В. В. Веснін, О. Г. Фадєєв [та ін.] // Травма. - 2017. - № 8 (3).

2. Filip M. Vanhoenacker. Imaging features of extraaxial musculoskeletal tuberculosis / M. Filip // Indian J. Radiol. Imaging. - 2009. - No. 19 (3). - P. 176-186.

3. Chen C. H. Early diagnosis of spinal tuberculosis / C. H. Chen // Journal of the Formosan Medical Association. - 2016. - No. 115. - P. 825-836.

4. Kasalak Ö. Culture yield of repeat percutaneous image-guided biopsy after a negative initial biopsy in sus-
Висновки. МРТ $є$ найкращим методом для діагностики спондилітів. За показниками чутливості, точності, прогностичності та ефективності МРТ випереджає інші методи радіологічної візуалізації. Це єдиний з методів, який дозволяє виявляти набряк кісткового мозку та має значні переваги у виявленні поширення процесу на спинний мозок, оболонки мозку та інші м'які тканини. Дані КТ найкраще характеризують диференційні особливості кістководеструктивного процесу і паравертебральних абсцесів при ТС і НС. Поєднане застосування КТ+МРТ значно підвищує специфічність і точність діагностики, порівняно з самим лише МРТ. Використання ЦТ підвищує діагностичні можливості рентгенологічного методу. 3 точки зору ефективності використання ресурсів та меншого променевого навантаження перспективним є поєднання ЦТ+МРТ.

pected spondylodiscitis: a systematic review / Ö. Kasalak // Skeletal Radiology. - 2018. - No. 47. - P. 1327-1335.

5 . Kim J. Outcome of culture-negative pyogenic vertebral osteomyelitis: Comparison with microbiologically confirmed pyogenic vertebral osteomyelitis / J. Kim // Seminars in Arthritis and Rheumatism. - 2014. - No. 44 (2). P. 246-252.

6. Ramadani N. Radiologic diagnosis of spondylodiscitis, role of magnetic resonance / N. Ramadani // Acta Inform. Med. - 2017. - No. 25 (1). - P. 54-57.

\section{REFERENCES}

1. Holka, H.H., Vesnin, V.V., Fadieiev O.H., Burlaka V.V., Oliinyk, A.O., \& Harkusha, M.A. (2017). Zahalni pryntsypy diahnostyky tuberkuloznoho spondylitu [General principles of diagnosis of tuberculous spondylitis]. Travma - Trauma, 8 (3) [In Ukrainian].

2. Filip M. Vanhoenacker (2009). Imaging features of extraaxial musculoskeletal tuberculosis. Indian J. Radiol. Imaging, 19 (3), 176-186.

3. Chen, C.H. (2016). Early diagnosis of spinal tuberculosis. Journal of the Formosan Medical Association, 115, 825-836.
4. Kasalak, Ö. (2018). Culture yield of repeat percutaneous image-guided biopsy after a negative initial biopsy in suspected spondylodiscitis: a systematic review. Skeletal Radiology, 47, 1327-1335.

5. Kim, J. (2014). Outcome of culture-negative pyogenic vertebral osteomyelitis: Comparison with microbiologically confirmed pyogenic vertebral osteomyelitis. Seminars in Arthritis and Rheumatism, 44 (2), 246-52.

6. Ramadani, N. (2017). Radiologic diagnosis of spondylodiscitis, role of magnetic resonance. Acta Inform. Med., 25 (1), 54-57.

\title{
ИНФОРМАТИВНОСТЬ И ЭФФЕКТИВНОСТЬ ЛУЧЕВЫХ МЕТОДОВ В ДИАГНОСТИКЕ СпОНдилитов
}

\author{
○Н. В. Дереш ${ }^{1}$, Е. П. Шармазанова² \\ ${ }^{1}$ Диагностический центр "Омега-Киев», \\ ${ }^{2}$ Харковская медицинская академия последипломного образования
}

РЕЗЮМЕ. Золотым стандартом диагностики спондилитов является культуральная или патоморфологическая верификация. Однако проведение интервенционных хирургических вмешательств с диагностической целью при спондилите имеет ряд ограничений. Результаты биопсии требуют осторожной интерпретации, без визуали- 
Огляди літератури, оригінальні дослідження, погляд на проблему, випадок з практики, короткі повідомлення зационной навигации возможны негативные результаты, имеют место важные методологические проблемы и низкое качество полученного материала. При невозможности гистологической или бактериологической верификации лучевая диагностика становится единственным критерием подтверждения диагноза.

Цель - определить информативность и эффективность рентгенографии, компьютерной томографии (КТ), магнитно-резонансной томографии (МРТ), цифрового томосинтеза (ЦТ) и их сочетаний в диагностике спондилитов.

Материал и методы. Проведено ретроспективное исследование 140 взрослых пациентов, из них 54 с туберкулезным спондилитом, 41 с неспецифическим спондилитом и 45 человек, составивших контрольную группу.

Результаты. Определены чувствительность, специфичность, точность, прогнозируемость и эффективность каждого из лучевых методов, а также комбинаций МРТ и КТ, МРТ и цифрового томосинтеза.

Выводы. МРТ оказался лучшим методом диагностики спондилитов. Это единственный из методов, который позволяет выявлять отек костного мозга и имеет значительные преимущества в выявлении распространения процесса на спинной мозг, оболочки и другие мягкие ткани. Данные КТ лучше всего характеризуют дифференциальные особенности костно-деструктивного процесса и паравертебральных абсцессов. Сочетанное применение КТ+МРТ повышает специфичность и точность диагностики. ЦТ повышает диагностические возможности рентгенологического метода. С точки зрения эффективности использования ресурсов и меньшей лучевой нагрузки перспективным является сочетание цифрового томосинтеза и МРТ.

КЛЮЧЕВЫЕ СЛОВА: спондилит; рентгенография; компьютерная томография; магнитно-резонансная томография; цифровой томосинтез; специфичность; чувствительность; эффективность.

\title{
DIAGNOSTIC VALUE AND EFFICIENCY OF RADIOLOGICAL IMAGING IN DIAGNOSING SPONDYLITIS
}

\author{
@N. V. Deresh1, O. P. Sharmazanova² \\ ${ }^{1}$ Diagnostic center "Omega-Kyiv", \\ ${ }^{2}$ Kharkiv Medical Academy of Postgraduate Education', Ukraine
}

SUMMARY. The gold standard for the diagnosis of spondylitis is cultural or pathomorphological verification. However, performing interventional surgical interferences for diagnostic purposes with spondylitis have limitations. Biopsy results require careful interpretation; negative results are possible without visual navigation, important methodological problems and poor quality of the material obtained. If histological or bacteriological verification is not possible, diagnostic imaging, become the only one way for confirming the diagnosis.

The aim - to determine diagnostic value and efficiency of radiography, CT, MRI, digital tomosynthesis and their combinations in diagnosing spondylitis.

Material and Methods. Retrospective study of 140 adult patients, including 54 with tuberculous spondylitis, 41 with nonspecific and 45 - control group.

Results. The sensitivity, specificity, accuracy, predictivity and effectiveness of each of the methods, as well as combinations of MRI and CT, MRI and digital tomosynthesis are determined.

Conclusions. MRI is the best method for diagnosing spondylitis. Only MRI can detect bone marrow edema and has significant advantages in detecting the spread of the process to the spinal cord, meninges and other soft tissues. CT data best describes the differential features of the bone-destructive process and paravertebral abscesses. The combined CT+MRI increases the specificity and accuracy of diagnosis. CT increases the diagnostic capabilities of the X-ray method. From the point of view of resource efficiency and lower radiation exposure, the combination of digital tomosynthesis and MRI is promising.

KEY WORDS: spondylitis; radiography; CT; MRI; digital tomosynthesis; specificity; sensitivity; efficiency.

Отримано 12.02.2020 